Available online: http://openjournal.wdh.ac.id/index.php/edudharma

Edu Dharma Journal: Jurnal Penelitian dan Pengabdian Masyarakat

ISSN (Print) 2597-890 X , ISSN (Online) 2686-6366

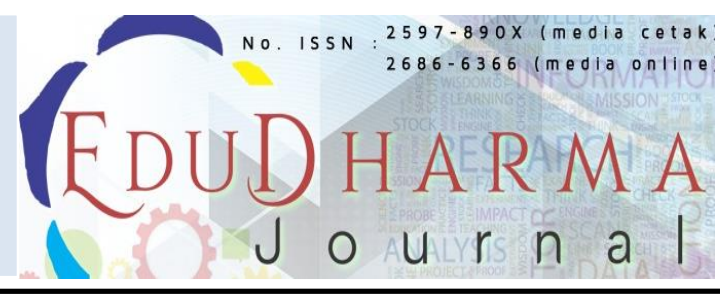

\title{
STUDI KUALITATIF PERSEPSI DAN PERILAKU PEKERJA SEKS KOMERSIAL DALAM UPAYA PENCEGAHAN INFEKSI MENULAR SEKSUAL DAN HIV/AIDS DI BOGOR
}

\author{
Siti Novy Romlah ${ }^{1 *}$, Riris Andriati ${ }^{2}$, Mahfuj Putra Utama ${ }^{3}$ \\ ${ }^{1,2}$ Dosen STIKes Widya Dharma Husada Tangerang, Jl. Pajajaran No. 1 Pamulang, Tangerang Selatan 15417, Indonesia \\ ${ }^{3}$ Mahasiswa Program Studi S1 Keperawatan STIKes Widya Dharma Husada Tangerang, Jl. Pajajaran No. 1 Pamulang, Tangerang \\ Selatan 15417, Indonesia
}

\begin{tabular}{|c|c|}
\hline ARTICLE INFORMATION & $A B S T R A C T$ \\
\hline $\begin{array}{l}\text { *Corresponding Author } \\
\text { Siti Novy Romlah } \\
\text { E-mail : sitinovyromlah@wdh.ac.id }\end{array}$ & $\begin{array}{l}\text { Background: Sexually transmitted infections (STIs) can increase the risk } \\
\text { of infection with the Human Immunodefficiency Virus (HIV), therefore } \\
\text { someone who has been affected by STIs will be more easily infected with } \\
\text { HIV, especially in commercial sex workers (CSWs). From } 2014 \text { to } 2017 \\
\text { in Bogor cases of STIs and HIV / AIDS were mostly caused by }\end{array}$ \\
\hline $\begin{array}{l}\text { Keywords: } \\
\text { Perception_1 } \\
\text { Behavior_2 } \\
\text { Sexual Transmitted Infection_3 } \\
\text { HIV/AIDS_4 }\end{array}$ & $\begin{array}{l}\text { Throughout } 2017 \text { to } 2018 \text { there have been more than } 554 \text { sufferers of } \\
\text { HIV / AIDS recorded in Bogor. Objective: The purpose of this study was } \\
\text { to determine the perceptions and behavior of commercial sex workers in } \\
\text { an effort to prevent sexually transmitted infections and HIV / AIDS using } \\
\text { the theory of Health Belief Model in Bogor. This research is a qualitative } \\
\text { research with a snowball sampling approach. The main informants in } \\
\text { this study were CSWs which numbered } 5 \text { people. Results: The results of } \\
\text { this study indicate that the driving factor for working as a prostitute is } \\
\text { because of the economy and debt management, knowledge of CSWs } \\
\text { when it is low for prevention of sexually transmitted infections and HIV / } \\
\text { AIDS, overall CSWs are aware of the perception of the benefits of } \\
\text { prevention efforts but only check the team medical, the perception of } \\
\text { self-awareness of STIs and HIV / AIDS is very lacking because } \\
\text { commercial sex workers do not question consumers not using condoms } \\
\text { when they are intimate. Conclusion: Characteristics of CSWs, } \\
\text { Informants ranged from the youngest of } 25 \text { years and the oldest of } 36 \\
\text { years, } 3 \text { informants worked as CSWs for } 1-6 \text { months. Apart from these } \\
\text { informants, they worked as prostitutes for } 2 \text {-4 years, } 5 \text { widow status } \\
\text { informants. All informants had low levels of education. The driving } \\
\text { factor for informants to undergo work as commercial sex workers is } \\
\text { because of economic factors. }\end{array}$ \\
\hline $\begin{array}{l}\text { Kata Kunci: } \\
\text { Persepsi_1 } \\
\text { Perilaku_2 } \\
\text { Infeksi Menular Seksual_3 } \\
\text { HIV/AIDS_4 }\end{array}$ & $\begin{array}{l}\text { A B S T R A K } \\
\text { LatarBelakang : Infeksi menular seksual (IMS) dapat meningkatkan } \\
\text { risiko terinfeksi Human Immunodefficiency Virus (HIV), oleh karena itu } \\
\text { seseorang yang sudah terkena IMS akan lebih mudah tertular HIV } \\
\text { terutama pada pekerja seks komersial (PSK). Dari tahun } 2014 \text { sampai } \\
\text { tahun } 2017 \text { di Bogor kasus IMS dan HIV/AIDS lebih banyak disebabkan } \\
\text { karena penularan dari PSK yang sudah tertular IMS dan HIV/AIDS. } \\
\text { Sepanjang tahun } 2017 \text { sampai tahun } 2018 \text { Sudah lebih dari } 554 \text { penderita } \\
\text { HIV/AIDS yang terdata di Bogor. Tujuan : Tujuan dalam penelitian ini } \\
\text { adalah untuk mengetahui persepsi dan perilaku pekerja seks komersial }\end{array}$ \\
\hline
\end{tabular}




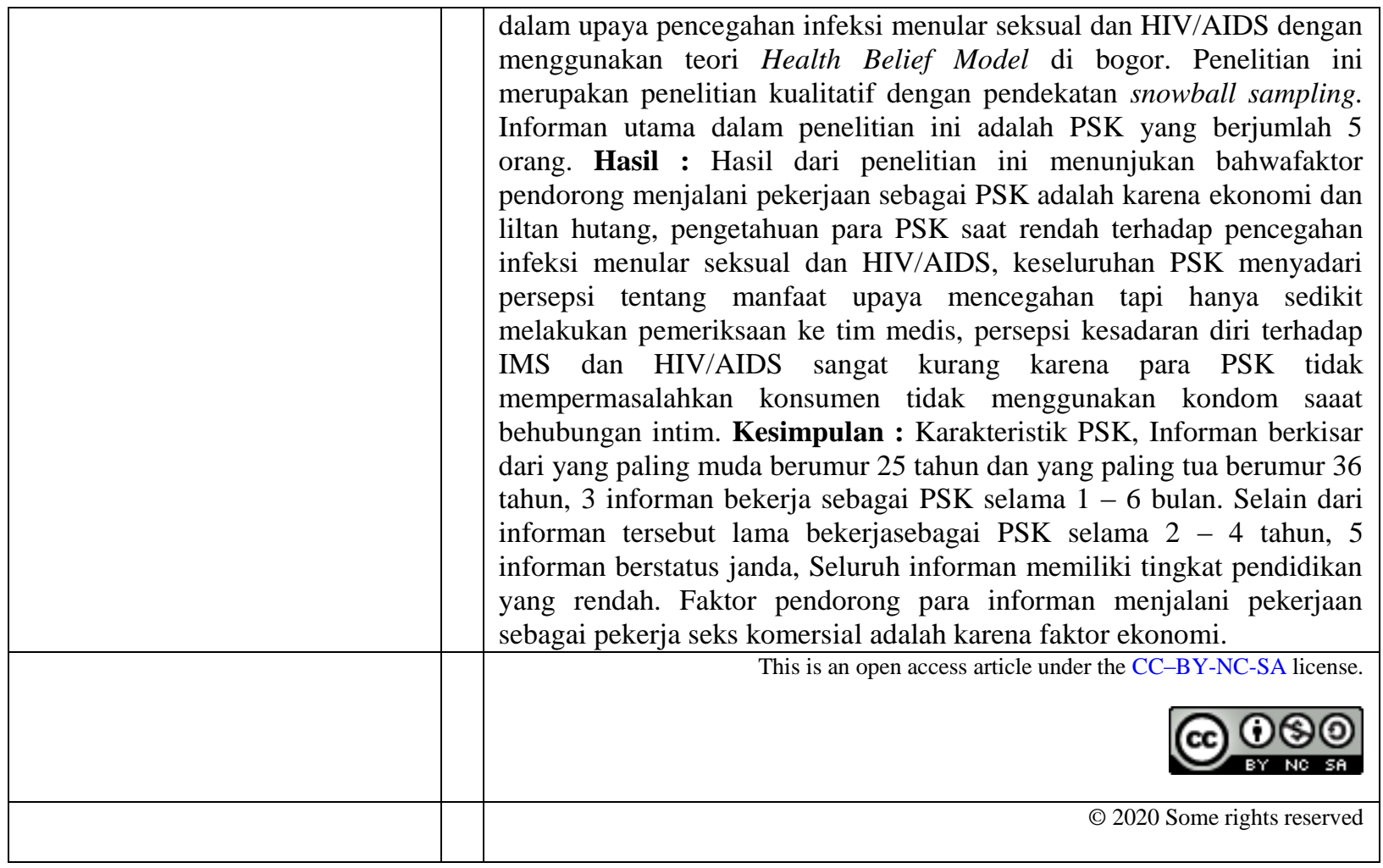




\section{PENDAHULUAN}

Profesi sebagai pekerja seks komersial (PSK) sangat berisiko memiliki dampak yang negatif terhadap kesehatan maupun terhadap lingkungan sosial. PSK berisiko tertular Penyakit Menular Seksual atau disebut dengan Infeksi Menular Seksual (IMS). IMS dapat meningkatkan risiko terinfeksi HIV oleh karena itu seseorang yang sudah terkena IMS akan lebih mudah tertular HIV (Kementrian Kesehatan RI, 2015, Astrini et al, 2020).

Terdapat lebih kurang 30 jenis mikroba (bakteri, virus, dan parasit) yang dapat ditularkan melalui hubungan seksual. Dalam semua masyarakat, IMS merupakan penyakit yang paling sering dari semua infeksi. Secara epidemiologi penyakit ini tersebar di seluruh dunia, angka kejadian paling tinggi tercatat di Asia Selatan dan Asia Tenggara, diikuti Afrika bagian Sahara, Amerika Latin, dan Karibean. (WHO, 2009). Di Amerika, jumlah wanita yang menderita infeksi klamidial 3 kali lebih tinggi dari lakilaki. Dari seluruh wanita yang menderita infeksi klamidial, golongan umur yang memberikan kontribusi yang besar ialah umur 15-24 tahun. Dewasa dan remaja (1524 tahun) merupakan $25 \%$ dari semua populasi yang aktif secara seksual, tetapi memberikan kontribusi hampir $50 \%$ dari semua kasus IMS baru yang didapat. Kasus - kasus IMS yang terdeteksi hanya menggambarkan 50 $80 \%$ dari semua kasus IMS yang ada di Amerika. Berdasarkan data WHO yang melakukan penelitian dibeberapa Negara berkembang menunjukkan sekitar $12 \%$ telah positif terkena IMS dan $27 \%$ positif HIV (Mangando, 2014).

Jumlah infeksi HIV tertinggi yaitu di DKI Jakarta (43.738), diikuti Jawa Timur (28.979), Papua (23.450), Jawa Barat (21.281) dan Jawa Tengah (15.710). Berdasarkan data tersebut Provinsi Jawa Barat termasuk peringkat ke 4 yang memiliki jumlah kasus HIV tertinggi di Indonesia. Begitu juga dengan kasus AIDS di Jawa Barat yang menempati urutan ke 6 (4.936) setelah Jawa Tengah (5.611) dan Bali ( 6.305). (Kemenkes RI, 2018).

Dinas Kesehatan (Dinkes) Kabupaten Bogor, Jawa Barat menemukan ada 290 orang penderita baru penyakit HIV/AIDS sepanjang tahun 2018 dengan mayoritas adalah laki-laki. Secara keseluruhan sejak 2017 hingga 2018 tercatat sekitar 554 penderita HIV/AIDS yang terdata. Untuk tahun 2018 saja sampai Desember 2018 ada 290 orang. Dari temuan kasus baru selama 
2017-2018 tambahnya, mayoritas juga

masih berusia produktif antara 25-49 tahun,

kebanyakan

dari jenis kelamin laki-laki. (Dinkes Kab Bogor, 2018).

Berdasarkan studi pendahuluan yang dilakukan peneliti pada tanggal 25 Maret 2019 pada mucikari di Bogor, diperoleh informasi bahwa persepsi dan perilaku para PSK terhadap upaya pencegahan IMS dan HIV/AIDS masih kurang baik dalam menjaga organ reproduksi, begitupun dalam hal penanganan dan pengobatan gangguan organ reproduksi masih kurang optimal. Oleh karena itu peneliti tertarik untuk melakukan penelitian dengan judul studi kualitatif persepsi dan perilaku pekerja seks komersial dalam upaya pencegahan infeksi menular seksual dan HIV/AIDS di bogor.

\section{METODE PENELITIAN}

\section{Desain Penelitian}

Penelitian ini merupakan penelitian yang bersifat kualitatif yaitu suatu pendekatan penelitian yang menghasilkan data deskriptif berupa data- data tertulis atau lisan dari orang-orang dan pelaku yang diamati.

Pemilihan informan pada penelitian ini menggunakan metode snowball sampling (bola salju). Peneliti berangkat dari seorang informan untuk mengawali pengumpulan data. Kepada informan peneliti menanyakan siapa saja orang yang selayaknya untuk diwawancarai (Pawito, 2007).

\section{Sampel}

Sampel dalam penelitian kualitatif bukan dinamakan narasumber, tetapi sebagai narasumber, atau partisipan, informan, teman dan guru dalam penelitian. Sampel dalam penelitian kualitatif juga bukan disebut sampel statistik, tetapi sampel teoritis karena tujuan penelitian kualitatif adalah untuk menghasilkan teori (Arikunto,2012). Pada penelitian ini jumlah informan utama yang diteliti sebanyak 10 orang.

\section{Cara Pengumpulan Data}

Pada penelitian ini peneliti menggunakan metode wawancara mendalam agar peneliti mendapatkan keterangan secara lisan dari informan untuk mendapatkan keterangan dan data diri individu untuk keperluan informasi yang dibutuhkan dalam penelitian informan untuk mendapatkan jawaban yang lebih lengkap. Metode pengambilan data

Pada penelitian ini peneliti menggunakan metode wawancara mendalam agar peneliti mendapatkan keterangan secara lisan dari informan untuk mendapatkan keterangan dan data diri individu untuk keperluan informasi yang dibutuhkan dalam penelitian 
(Sugiyono, 2018). Peneliti akan melakukan probing dengan mengajukan pertanyaan yang lebih terinci pada poin - poin pertanyaan saat wawancara informan untuk mendapatkan jawaban yang lebih lengkap.

\section{HASIL DAN PEMBAHASAN}

\section{Identitas Informan}

\section{Deskripsi Umur}

a. Narasumber F

F adalah pekerja seks komersial berumur 36 tahun dan berstatus Ibu Rumah Tangga. Berlatar belakang dari keluarga yang tidak mampu. Bertemu $\mathrm{F}$ terkesan sebagai individu yang ramah dan cukup terbuka walupun ketika di wawancarai sedikit ketakutan, karena ketika peneliti mewawancarai F. F masih terhitung baru sebagai pekerja seks, F di ajak oleh teman untuk bekerja sebagai pekerja seks komersial.

b. Narasumber L

$\mathrm{L}$ adalah pekerja seks komersial berumur 25 tahun dan berstatus Ibu Rumah Tangga. Berlatar belakang dari keluarga yang tidak mampu dan di tinggal kabur oleh suaminya. Bertemu L terkesan sebagai individu yang seidikit tidak ramah saat di wawancarai, L masih terhitung sudah lama sebagai pekerja seks, L menggeluti sebagai pekrja seks komersial diawali oleh diri sendiri yang lahir di lingkungan yang seperti itu.

\section{c. Narasumber M}

M adalah pekerja seks komersial berumur 27 tahun dan berstatus Ibu Rumah Tangga. Berlatar belakang dari keluarga yang tidak mampu. Bertemu $M$ terkesan sebagai individu yang komunikatif dan cukup terbuka, ia tidak takut ketika diwawancarai oleh peneliti, karena yang dia pikir tidak peduli walaupun identitiasnya terbongkar, yang ia lebih pentingkan adalah uang, karena ketika peneliti mewawancarai M. M masih terhitung baru sebagai pekerja seks, M sama seperti dengan L, yang terjun sebagai pekerja seks komersial karena melihat lingkungannya, karena di asli lingkungan sekitar

\section{d. Narasumber I}

I adalah pekerja seks komersial berumur 26 tahun, status sebagai janda, karena ditinggaal kabur oleh suaminya dan terpaksa memilih pekerjaan ini karena untuk memenuhi kebutuhuan kedua anaknya dan membayar hutang, I diajak oleh teman untuk kerja di malaysia sebagai pekerja seks komersial, setelah suaminya tak ada kabar selama 4 bulan, dan I sudah mencari sang 
suami ke saudara dan teman sejabat sang suami tapi tak menuaikan hasil, dan akhirnya I langsung ikut temannya itu pergi ke malaysia, sesampai nya di malaysia I di masukin di rumah bordil atau di malaysia di sebut mamah ayam yang di miliki oleh orang Medan yang sudah lama tinggal di malaysia.

e. Narasumber P

$\mathrm{P}$ adalah pekerja seks komersial berumur 28 tahun dan berstatus Ibu Rumah Tangga. Berlatar belakang dari keluarga yang tidak mampu dan di tinggal meninggal oleh suaminya. Bertemu $\mathrm{P}$ terkesan sebagai individu yang sedikit tidak ramah saat di wawancarai, F masih terhitung sudah lama sebagai pekerja seks, P menggeluti sebagai pekerja seks komersial diawali oleh diri sendiri yang lahir di lingkungan yang seperti itu.

\section{Pendidikan Terakhir}

Rata-rata Pendidikan terakhir dari 5 informan yaitu 3 informan hanya lulusan SD dan 2 lainnya lulusan SMP.

\section{Informasi “Bekerja”}

a. Tempat Bekerja

Berdasarkan 5 informan, ke 3 informan biasa bekerja atau mangkal di seputar jalan raya Bogor.

"iya sepanjang jalan ini aja”
Berbeda dari ke 3 yang di atas, 1 informan mengatakan biasa mangkal di seputar jalan raya Bogor tapi terkadang pindah-pindah.

"Emang biasa nya disini, tapi suka pindah $s i$ ” (informan M)

Berbeda dari ke 4 informan diatas, informan I baru memulai atau mencoba mangkal di jalan raya Bogor, dikarenakan sebelumnya dia bekerja di Malaysia sebagai PSK.

"Baru mangkal disini, baru Pulang dari Malaysia kemaren” (informan I).

b. Lama bekerja

Berdasarkan lama bekerja dari 5 informan bermacam-macam ada yang baru bekerja sebagai pekerja seks komersial masih 5 bulan sampai 6 bulan dan ada yang sudah 1 tahun, 2 tahun dan sampai 4 tahun.

c. Pelayanan informan

Informan F

Pelayanan yang ditawarkan oleh $\mathrm{F}$ adalah oral, petting, dan hubungan kelamin. Oral adalah memasukan buah zakar ke mulut. Petting adalah istilah asing untuk bercumbu atau saling berciuman. F mematok tarif pelayanan di atas sebesar Rp 300.000,00 untuk satu kali pelayanan kepada konsumen yang ingin memakai jasanya. $\mathrm{F}$ menggunakan kamar kontrakan sebagai tempat pelayanan. $\mathrm{F}$ benar-benar memperhatikan pelayanan seksnya. Tarif yang telah disebutkan di atas adalah paket 
pelayanan lengkap yang diberikannya kepada konsumen. Jenis pelayanan seks berpengaruh terhadap tarif dan tergantung dari kesepakatan dengan konsumen.

\section{Narasumber L}

$\mathrm{L}$ berbeda dengan $\mathrm{F}$ dalam hal memanjakan konsumen dengan pelayanan seksnya. L membatasi antara hubungan kelamin dengan petting. Pelayanan $\mathrm{L}$ adalah hubungan kelamin sekaligus petting tanpa oral, berbeda dengan $\mathrm{F}$ yang membatasi keduanya yang memungkinkan terjadinya perubahan tarif pelayanan dalam negosiasi. Hal ini merupakan manajemen yang diterapkan oleh setiap perempuan pekerja seks berbedabeda. L mematok tarif sebesar $\mathrm{Rp}$ 200.000,00 sampai $\mathrm{Rp} \mathrm{500.000,00} \mathrm{untuk}$ sekali pelayanan di tempat kontrakannya.

\section{Narasumber M}

Sama halnya dengan F, M melayani yang ditawarkan oleh $\mathrm{M}$ adalah oral, petting, dan hubungan kelamin. Oral adalah memasukan buah zakar ke mulut. Petting adalah istilah asing untuk bercumbu atau saling berciuman. $\mathrm{M}$ mematok tarif pelayanan di atas sebesar $\mathrm{Rp} 250.000,00$ sampai $\mathrm{Rp}$ 600.000,00 untuk satu kali pelayanan kepada konsumen yang ingin memakai jasanya. M menggunakan kamar kontrakan sebagai tempat pelayanan. $\mathrm{M}$ benar-benar memperhatikan pelayanan seksnya. Tarif yang telah disebutkan di atas adalah paket pelayanan lengkap yang diberikannya kepada konsumen. Jenis pelayanan seks berpengaruh terhadap tarif dan tergantung dari kesepakatan dengan konsumen.

Narasumber I

Pelayanan yang ditawarkan oleh I sama dengan $\mathrm{F}$ adalah oral, petting, dan hubungan kelamin. Oral adalah memasukan buah zakar ke mulut. Petting adalah istilah asing untuk bercumbu atau saling berciuman. I tidak dapat mematok tarif, karena untuk tarif sudah di buat oleh pemilik tempat mamah ayam tersebut, pengakuan dari I tarif yang 60 Ringgit Malaysia, kalau di rupiahkan sekitar Rp 180.000,00, beda hal nya dengan F, L, dan M, untuk jasa pelayanan kepada konsumen yang ingin memakai jasanya menggunakan waktu per15menit. Untuk tempat sudah di sediakan kamar oleh pemilik mamah ayam sebagai tempat pelayanan. $\mathrm{F}$ benar- benar memperhatikan pelayanan seksnya. Tarif yang telah disebutkan di atas adalah paket pelayanan lengkap yang diberikannya kepada konsumen. Apabila lewat dari 15 menit, maka di kenakan biaya tambahan yang di sepakati oleh mamah ayam 
Narasumber P

Pelayanan yang ditawarkan oleh $\mathrm{P}$ adalah oral, petting, dan hubungan kelamin. Oral adalah memasukan buah zakar ke mulut. Petting adalah istilah asing untuk bercumbu atau saling berciuman. F mematok tarif pelayanan di atas sebesar $\mathrm{Rp} 300.000,00$ sampai Rp 500.000,00 untuk satu kali pelayanan kepada konsumen yang ingin memakai jasanya. $\mathrm{P}$ menggunakan kamar kontrakan sebagai tempat pelayanan. $\mathrm{P}$ benar-benar memperhatikan pelayanan seksnya. Tarif yang telah disebutkan di atas adalah paket pelayanan lengkap yang diberikannya kepada konsumen. Jenis pelayanan seks berpengaruh terhadap tarif dan tergantung dari kesepakatan dengan konsumen.

\section{d. Tarif}

Dari 5 informan, 4 informan rata-rata tarif 300 sampai 600an perkali melayani konsumennya, sebagai berikut kutipan salah tau informan.

"Aku mah 300, paling kecil 250, 500 terus paling gede $600 ”$.

Sedangkan informan I tarif melayani menggunakan uang ringgit malaysia, dikarenakan lama berkerjanya di malaysia 4 tahun lama nya, jadi informan belum pasti menghargai tarifnya
"60 ringgit Malaysia per 15menit, Sekitar seratus depan puluh ribu (180rb)"

(Informan mengatakan tarif tersebut adalah tarif saat informan berkerja di Malaysia).

\section{Status Pernikahan}

Dari kelima informan semua informan berstatus janda atau sudah bercerai, ada yang sudah di tinggal meninggal dunia dan ada yang di tinggal oleh sang suami, "Iya sekarang mah si udaah cerai, jadi janda, iya aku kan di tinggal suami”, (informan I mengatakan sebari meminum teh manis) (informan p)

\section{Deskripsi Pekerjaan}

Sebelum informan bekerja sebagai pekerja seks komersial (PSK), ada yang bekerja di PT, Garmen, toko laundry, pembantu dan konter HP. Mereka memilih meninggalkan pekerjaan tersebut ada yang beralesan kerja di tempat tersebut melelahkan dan gaji kecil.

"Aku pernah kerja di garmen, tapi aku ngga lama gitu, soalnya aku ngga kuat berdiri" (informan F).

Dari 5 informan alasan memilih pekerjaan PSK adalah dikarenakan alasan ekonomi, dan lebih simpel dalam waktu bekerjanya. "Sebenernya ga pengen, Cuma nyari yang simple-simpel aja deh, udah cape kerja, kalau gini kan enak ada waktu dirumah, jadi bisa semaunyalah" (informan P). 
Dari 5 informan, 3 informan mengetahui dan diajak bekerja sebagai pekerja seks komersial (PSK) di ajak dari teman sejabat. " Iya awalnya ikut-ikutan, iya kan kita mah masih baru ya.. jadi belom tau apa-apa masalahnya gitu, masalah nya main di jalan belom tau, jadi nanya-nanya selalu ketementemen, gini gin gini gitu kata temen-temen, kalau sekaarang mah tapi udaaah tau" (informan F)

Sedangkan 2 informan tahu dan memilih kerja ini karena sudah tau sendiri karena lingkungan informan tersebut adalah area lingkungan para pekera tersebut.

"Kan aku udah tinggal disini lama, jadi aku mah terjun sendiri aja” (informan M)

\section{Pengetahuan}

\section{a. Pengetahuan tentang Infeksi Menular Seksual (IMS)}

Pengetahuan IMS Dari 5 informan, 3 informan tidak mengetahui apa itu infeksi menular seksual.

"engga tahu saya gak pernah denger" (informan F)

Sedangkan ke 2 informan mengetahui IMS, walaupun tidak tahu spesifik, tapi kata mereka, mereka tau dari televisi dan dari temen menceritakan penyakit tersebut.

"lewat hubungan ya? Soalnya saya sering liat di Tv waktu masih kerja di majikan dulu” (informan P)

\section{Jenis-jenis Penularan IMS}

Dari kelima informan, semua tidak mengetahui jenis-jenis penyakit infeksi menular dan juga tidak mengetahui gejalagejala apa saja dari infeksi menular seksual tersebut

"Infeksi gitu si, .. Kalau gejala- gejala nya si kurang tau” (informan L)

Sedangkan ada 1 informan yang mengira infeksi menular itu HIV, karena yang dia takutin yaitu hanya HIV.

“Apa ya? Takut HIV' (informan L)

\section{Cara penularan IMS}

Bersadarkan kelima informan semua mengatakan bahwa cara penularan infeksi menular seksual yaitu dengan pasangan atau hubungan intim.

"Gatau juga ya, iya kali hubungsn intim mereun," (informan F).

\section{Upaya pencegahan IMS}

Kelima informan tidak sama sekali mengetahui cara upaya pencegahan terhadap penyakit infeksi menular seksual (IMS), sangat disayangi karena mereka adalah salah satu para pekerja yang sangat berisiko terkena infeksi menular seksual tersebut, kutipan

"Iya aku mah gatau kaya gituan mah" 
(informan F)

\section{b. Pengetahuan tentang HIV/AIDS a. Pengetahuan HIV/AIDS}

Berdasarkan 5 informan, 3 informan menjawab tidak mengetahui penyakit HIV/AIDS, sedangkan 2 informan memilki jawaban berbeda.

"Iya gitu katanya mah dari Rahim ya cewe nya mah, katanya mah misalnya penyakit HIV Asalnya dari kita juga tapi gatau benernya mah, tapi tau denger dengernya aja" (informan F)

Berbeda dengan informan 3 yang tidak mengetahui HIV/AIDS dan informan $\mathrm{F}$, informan I mengetahu penyakit HIV/AIDS tersebut dari teman sepekerja nya yang menderita penyakit tersebut.

"Iya gtu, temen aku sebelum pulang Batam, di vonis kena HIV, terus divonis usia hidupnya ga lama gitu, selang berapa bulan atau minggu, dia sudah meninggal" ( cerita informan I atas penyakit teman yang diderita).

\section{Gejala-gejala HIV/AIDS}

Dari ke 5 informan, semua mengatakan tidak mengetahui gejala bagaimana HIV/AIDS terjadi pada penderita.

"gatau yah" (semua informan mengatakan ketidak tahuannya terhadap gejala yang di timbulkan oleh HIV/AIDS”)

\section{Cara penularan HIV/AIDS}

Berdasarkan ke 5 informan, 2 tidak mengetahui cara penularan HIV/AIDS secara jelas, akan tetapi 3 informan berbeda menjawab bahwa caraa penularan HIV/AIDS di dasarkan pada hubungan intim yang bergunta- ganti pasangan.

"Karena gunta ganti pasangan" (informan L)

\section{Deksripsi Persepsi}

a. Persepsi tentang Kerentanan terhadap Keparahan Infeksi Seksual Menular dan HIV/AIDS.

Apakah anda beresiko terkena IMS dan HIV/AIDS?

Dari 5 informan, 1 informan mengatakan tidak mengetahui apakah diri nya tersebut beresiko atau tidak

"Gatau "( geleng-geleng kepala ) (informan F)

Sedangkan 4 informan mengatakan bahwa mereka berisko terkena infeksi menular seksual dan HIV/AIDS,

"Iya mau gamau, iya resiko bahaya yang kita hadapin, iya minum obat aja lah biar ga sakit, " (informan M).

Siapa aja yang beresiko terkena IMS dan HIV/AIDS

Dari ke 5 informan, 1 menyatakan tidak mengetahui siapa saja yang beresiko terkena penyakit infeksi menular seksual dan HIV/AIDS tersebut, sedangkan ke 4 informan yang lain mengatakan bahwa mereka salah satu yang sangat berisko 
terkena penyakit infeksi menular seksual dan HIV/AIDS.

"Maksudnya aku ga tau bener ya, tapi orang yang sering gunta-ganti pasanganan, walaupun pelanggannya ga usah pakai kondom aku sehat, tetap kan, kita juga, takut ,kan kita juga ga taukan ya kesehatan orang, istilahnya kan sedia payung sebelum hujan tapi kan aku berfikir begini ya, kan aku kerja nyari duit kalau aku terkena takut kan" (informan I).

\section{b. Persepsi terhadap keseriusan terkena infeksi menular seksual dan HIV/AIDS}

IMS dan HIV/AIDS itu Berbahaya atau Tidak?

Dari 5 informan, semua mengatakan bahwa infeksi menular seksual dan HIV/AIDS ini sangat berbahaya bagi mereka dan mereka takut terkena penyakit ini, sebagai berikut kutipan salah satu informan.

"Bahayalah, Iya takut nya kena HIV," (informan I)

\section{Dampak yang timbulkan oleh IMS dan}

\section{HIV/AIDS}

Dari ke 5 informan, 2 informan mengatakan tidak tahu bahaya seperti apa yang di timbulkan oleh infeksi menular seksual dan HIV/AIDS, 1 informan pun tidak mengetahui akan tetapi informan ini sedikit berbeda menjawabnya.

“ Ga tau ya, tapi kata nya kalau penyakit itu kan belum ada obatnya ya ? Bahaya" (informan L).

Sedangkan 2 informan lain mengatakan bahwa bila terkena infeksi menular seksual dan HIV/AIDS, dapat menyebabkan meninggal dunia.

"Denger dengernya mah nyawa ya taruhannya" (informan L).

\section{c. Persepsi terhadap manfaat upaya pencegahan yang dilakukan untuk mencegah tertularnya infeksi menular seksual dan HIV/AIDS}

Dari 5 informan 1 informan menatakan tidak tahu mengetahui upaya apa yang dilakakuan untuk pencegahan yang dilakukan, dan 2 informan menyakan hanya berobat ke apotek apa bila sakit pada tubuh dan membersihkan alat kemaluan setelah habis melayani konsumen.

"Iya di cegah, berobat gitu, Iya menjaga kalau habis main dibersihin” (informan M).

Sedangkan 1 informan memiliki jawaban berbeda yang di miliki.

"Iya atuh di cuci, Iya atuh masa didiemin, kita geh ga betah kan semua orang pasti gitu kan, masa kita bawa pulang hahahaha "(informan F).

Berbeda dari ke 2 informan di atas, informan ini melakukan upaya pencegahan dengan cara berobat ke rumah sakit. 
"Kan kita ada suntiknya antibiotic, jadi seminggu $2 x$ ke hospital, kalau di sini mungkin kaya rumah sakit gtu" (informan I).

Karena informan ini berkerja di Malaysia dan ketiak di Malaysia dia berkerja di bawah naungan atau sebuah rumah bordil yang memperkerjakan para pekerja seks komersial, yang akhirnya membuat peraturan untuk upaya pecegahan untuk memperiksakan diri ke rumah sakit Malaysia, agar terhindar dari kerugian yang tidak diinginkan

\section{Upaya yang telah dilakukan untuk pencegahan IMS dan HIV/AIDS}

Berdasarkan 5 informan, 3 mengatakan tidak mengetahui apa saja upaya yang sudah mereka lakukan, dikarenakan 3 informan tersebut sampai saat ini tidak merasakan penyakit di tubuh mereka, itu menjadikan mereka tidak ingin tahu pada penyakit infeksi menular seksual dan HIV/AIDS, sedangkan 1 informan mengatakan setelah melakukan hubungan intim pada konsumen, dia langsung membersihkan alat kelaminnya dengan air mengalir dan sbun batangan untuk tubuh, .

"Iya menjaga kalau habis main dibersihin pake sabun" (Informan M).

Sedangkan 1 informan lain telah melakukan upaya penyuntikan antibiotik pada tubuhnya, dan itu di lakukan dirumah sakit, karena itu intruksi dari majikan di tempat informan berkerja di Malaysia.

"Kalau aku ya, aku ,minum jamu antibiotic terus suntik antibiotic" (informan I

\section{Manfaat upaya pencegahan IMS dan HIV/AIDS}

Dari 5 informan, 3 mengatakan tidak tahu manfaat apa yang di dapati dalam upaya pencegahn tersebut, sedangkan 1 informan mengatakan rugi kalau sampai kena penyakit tersebut dapat merugikan uang dan tubuh, kutipan salah satu informan.

"Ga tau si, iya rugi juga kan kalau kena penyakit gitu, ngerusak badan' (informan $\mathrm{L})$.

Sedangkan informan 1 lagi mengtakan berbeda hal dari ke 4 informan di atas,

"Kalau aku ya, aku ,minum jamu antibiotic terus suntik antibiotic "(informan I)

\section{Deskripsi Perilaku}

a. Perilaku Pekerja Seks Komersial (PSK) dalam upaya penceagahan infeksi menular seksual dan HIV/AIDS

\section{Penggunaan Kondom saat Melayani}

\section{Konsumen}

Dari 5 informan, ke 4 informan menggunkan kondom saat melayani konsumen akan tetapi meraka pun melayani konsumen yang tidak menggunkan kondom, karena mereka 
mengikuti kemauan konsumennya.

“ Iya tergantung si mas nya aja” (informan M).

Informan $\mathrm{F}$ dan $\mathrm{M}$ mengikuti kemauan konsumennya, berbeda dari informan $\mathrm{F}$ dan M, informan L menyiapkan kondom untuk konsumen.

"Nyapin kok" (informan L).

Berbeda dari beberapa informan yang di atas, informan $\mathrm{P}$ tidak menyediakan kondom untuk konsumennya, dan malah konsumen yang menyediakan sendiri kondomnya

“ Iya kalau konsumen bawa iya pakai, kalau ga bawa, ya ga (informan P).

Sedangkan 1 informan memilki jawaban berbeda dari ke 4 informan di atas

"Selalu, tapi ada yang ga pakai, cuma harga nya tambah lagi”.

Informan ini menceritakan saat informan bekerja di Malaysia, untuk ketika saat ini kerja di boor atau bekerja sendiri, informan mengikuti kemauan konsumen).

\section{Penyediaan Kondom}

Dari ke 5 informan, 4 informan menjawab kadang menyediakan kondom, karean mereka merasa tidak perlu juga menyediakan, mereka menyediakan apabila kondom konsumen tertinggal, dan akhirnya di sediakan untuk konsumen lain itu pun apabila konsumen mau menggunakanya, sedangkan informan 1 lagi berbeda dari ke 4 informan yang lain yaitu kondom di sediakan oleh majikan atau tempat di bekerja sebagai PSK di tempat itu,

"Di sediakan di tempat kerja" (informan I) Himbauan Bahaya tentang tidak Pakai Kondom

Berdasarkan wawancara ke 5 informan, semua mengatakan tidak pernah mengingatkan konsumen tentang bahaya tertular penyakit infeksi menular sekual maupun HIV/AIDS, mereka merasa para konsumen sudah tau bahaya bila melakukan jasa meraka,

"Mereka semua udah tau sistem main di sana a, jadi ga perlu di kasih tau" (informan I menjelaskan sistem atau peraturan di tempat informan bekerja di Malaysia)

Penolakan saat Tidak Menggunakan Kondom

Dari 5 informan, 3 informan mengatakan tidak pernah meninggalkan konsumen saat berhubungan walaupun konsumen tidak menggunakan kondom, mereka mengatakan untuk meninggalkan bisa menyebabkan tidak dapat uang.

"Ketika mah ga pernah nolak, namanya juga jablay, kalau ninggalin ntar malah tidak dapet duit" (informan P). 
Informan 1 sama seperti di atas tapi agak berbeda dan mengatakan tidak pernah meninggalkan konsumen

karena alesan tidak pakai kondom, karena sudah ada aturannya di tempat informan ini bia tidak menggunakan kondom akan di kenakan biaya tambahan,

"Ya ga si, soalnya ada perjanjian sebelumnya kalau pakai kondom, kalau gamau pakai kondom nambah".

(Informan I menjelaskan sistem atau peraturan di tempat informan bekerja di Malaysia). Sedangkan 1 informan lain mengatakan meninggalkan karena tidak menggunakan kondom.

"Iya pernah, alesannya aku aja aku ga KB tapi padahal $\mathrm{KB}$, ntr kalau ga gitu kena ke Rahim aku" (informan M).

\section{Melayani Konsumen Berpenyakit Infeki}

\section{Menular Seksual atau pun HIV/AIDS}

Dari ke 5 informan, 4 mengatakan tidak tau jenis penyakit infeksi menular seksual jadi mereka tidak tau apakah pernah atau tidak melayani konsumen berpenyakit tersebut, karena mereka menyatakan tidak pernah melihat alat kelamin konsumen,

"Kan aku ga ngerti, ga merhatiin punya dia" (informan F).

Sedangkan 1 informan lain mengatakan pernah hampir melayani konsumen yang mengeluarkan nanah atau sejenis darah yang keluar dari alat kemaluan konsumen, akan tetapi informan ini menolak melayani konsumen tersebut karena merasa takut dengan alat kelamin konsumen seperti itu.

"Pernah lagi itu, berdarah dari ujung punya dia, aku ga tau kenapa ,Iya customernya, jadi dia mau sama aku, jadi sebelum berhubungan Kan kita sebelum main, kita liat dulu alat kelaminnya, Iya aku gamau" (informan I).

Apa informan pernah menderita IMS dan HIV/AIDS

Berdasarkan dari 5 informan, semua mengatakan tidak pernah menderita penyakit infeksi menular seksual ataupun HIV/AIDS "Alhamdulilah si, gak pernah, jangn deh amit" (informan P)

Hal ini mungkin karena merak tidak mengetahui jenis-jenis penyakit IMS, maka mereka mengatakan tidak mengetahui itu.

“Ga pernah, tau juga gak "(informan F)

\section{Pemeriksaan Keseahatan}

Ke 5 informan, 3 informan mengatakan bila sakit di bawa ke dokter, Puskesmas atau pun beli di apotek,

"Ya kalo sakit mah di bawa ke Puskesmas mereun di obatin masa didiemin "(informan F).

Berbeda dari ke 3 informan di atas, informan ini dia selalu melakukan pemeriksaan 1 minggu $2 \mathrm{x}$ ke rumah sakit untuk 
memeriksakan kesehatannya.

"Jadi seminggu $2 x$ ke hospital, hari kamis ama minggu, pagi atau siang a biasa nya, kan kalau malam kita kerja"(informan I).

\section{Penggunaan alat untuk pencegahan penyakit IMS dan HIV/AIDS}

Berdasarkan peryatakan ke 5 informan, semua hanya menggunkan kondom untuk pencegahaan penyakit infeksi menular dan HIV/AIDS pada diri mereka.

"Hmm iya paling kondom aja kali ya a" (informan I).

\section{b. Deskripsi Perilaku pencagahan}

\section{Kehamilan}

\section{Penggunaan Alat Kontrasepsi}

Dari 5 informan menyatakan mereka semua menggunkan KB suntik, implant dan spiral dan mereka menggunakan $\mathrm{KB}$ tersebut sudah lama sebelum berkerja sebagai pekerja seks komersial, dan KB itu di dapati dari bidaan terdekat dari rumah mereka. Dari 5 informan, 3 informan menyatakan tidak menstruasi karena $\mathrm{KB}$ yang mereka gunakan.

" Kalou nyuntik mah kan ga dapet mens, paling Cuma keluar darah kotorkotor gitu "(informan M).

\section{Gejala Kehamilaan Selama Bekerja Sebagai PSK}

Berdasarkan 5 informan mereka tidak pernah merasa gejala hamil selama berkerja sebagai pekerja seks komersial (PSK).

" Itu mah klo yang hamil mah ga jaga mereun, keenakan jadi kebablasan, masa kerja di jalanan bisa hamil. Ngaco"(informan F).

Sedangkan ada 1 cerita informan teman sejabat pekerja seks komersial (PSK) pernah mengalami kehamilan dan melahirkan, si calon bayi pernah di coab meminum obat keras, akan tetapi si calon bayi kuat dan tidak keguguran si teman informan tersebut hingga hamil dan melahirkan, akan tetapi si bayi di kasih kan kepada orang yang ingin merawat si bayi tersebut.

"Ada teman aku kalau hamil itu di hamilkan, terus anaknya dikasihkan ke orang yang mau merawat" (informan I mencertikan teman berkerjanya yang hamil).

\section{Sumber Informasi}

Dari 5 informan semua mengatakan tidak dapat sumber media informasi apapun tentang penyakit infeksi menular seksual (IMS) ataupun HIV/AIDS, mereka merasa sudah tidak perlu tau tentang hal semacam itu.

"Ga gatau uh, aku mah kan udah ga ada masa depan nya jadi semuanya buat anak aku aja, dari pada anak aku kelaperan” (informan $\mathrm{M}$ ).

\section{KESIMPULAN}

Berdasarkan penelitian yang dilakukan tentang persepsi dan perilaku pekerja seks 
komersial dalam upaya pencegahan IMS dan

HIV/AIDS di Kabupaten Bogor pada tahun

2019 didapatkan simpulan sebagai berikut:

1. Karakteristik PSK, Informan berkisar dari yang paling muda berumur 25 tahun dan yang paling tua berumur 37 tahun, 3 informan bekerja sebagai PSK selama $1-6$ bulan. Selain dari informan tersebut lama bekerjasebagai PSK selama $2-4$ tahun, 5 informan berstatus janda, Seluruh informan memiliki tingkat pendidikan yang rendah.

2. Faktor pendorong para informan menjalani pekerjaan sebagai pekerja seks komersial adalah karena ekonomi dan lilitan hutang yang memyebabkan mereka terpsaksa bekerja sabagai pekerja seks komersial (PSK) dan di tambah ada semua status mereka adalah janda, yang tidak ada orang atau kepala keluarga yang mencari nafkah untuk anak mereka.

3. Pengetahuan para pekerja seks komersial sangat rendah terhadap pencegahan penyakit infeksi menular seksual dan HIV/AIDS, ini di sebabkan dikarenakan pendidikan mereka yang rata-rata hanya lulusan SD saja.

4. Persepsi PSK tentang keseriusan dan kerentanan terhadap keparahan IMS dan
HIV/AIDS memiliki rasa kerentanan dan keseriusan yang tinggi terhadap penularan IMS dan HIV/AIDS sehingga mereka merasakan adanya ancaman bagi kesehatan mereka. PSK merasakan adanya ancaman bagi kesehatannya seharusnya dapat memunculkan sebuah perilaku, yaitu perilaku PSK dalam upaya pencegahan IMS dan HIV/AIDS. Namun pada kenyataannya, tingginya rasa kerentanan dan keseriusan terhadap suatu penyakit tidak berpengaruh

5. Faktor pendorong bagi PSK untuk melakukan upaya pencegahan IMS dan HIV/AIDS yaitu media informasi yang mereka dapatkan. Beberapa PSK mengatakan bahwa mereka pernah mendengar informasi tentang IMS dan HIV/AIDS dari Televisi dan pengalaman dari teman sebaya. Namun hanya 2 orang PSK yang mengatakan bahwa mereka pernah mendengar informasi tentang IMS dan HIV/AIDS dari tenaga kesehatan.

6. Persepsi tentang manfaat upaya pencegahan IMS dan HIV/AIDS, sebagian besar PSK menyadari manfaat dari upaya yang mereka lakukanagar terhindar dari penularan IMS atau HIV/AIDS seperti upaya memeriksakan diri ke tenaga kesehatan, mengkonsumsi 
antibiotik serta mengkonsumsi jamu atau ramu- ramuan yang dipercaya oleh mereka dapat menyembuhkan rasa sakitnya. Namun masih ada beberapa PSK yang belum menyadari manfaat dari upaya atau perilaku yang sering mereka lakukan terkait dengan kebersihan dirinya agar terhindar dari penularan IMS dan HIV/AIDS.

7. Persepsi tentang hambatan dalam upaya pencegahan IMS dan HIV/AIDS, hambatan yang dialami oleh beberapa PSK yaitu PSK memiliki rasa ketergantungan yang tinggi terhadap konsu men, maka mereka harus mengikuti keinginan konsumen jika tidak ingin menggunakan kondom pada saat berhubungan seksual. Serta kesadaran dari PSK terhadap keparahan penyakit yang dideritanya. Mereka belum bisa menyadari bahwa dirinya tertular atau tidaknya IMS atau HIV/AIDS, sehingga mereka hanya akan memeriksakan dirinya ke tenaga kesehatan jika penyakit yang ia derita sudah cukup parah. Adanya hambatanhambatan tersebut juga didasari oleh tingkat pendidikan, pengetahuan dan status ekonomi PSK yang rendah.

8. 8. Perilaku PSK dalam upaya pencegahan IMS dan HIV/AIDS Tingginya rasa kerentanan dan keseriusan serta manfaat dari upaya yang pencegahan yang PSK lakukan memang menimbulkan adanya suatu ancaman bagi kesehatan mereka sehingga memunculkan sebuah perilaku upaya pencegahan penyakit. Namun sebagian besar perilaku yang dimunculkan oleh PSK kurang tepat dalam upaya pencegahan IMS dan HIV/AIDS. Diantaranya seperti PSK tidak pernah mengingatkan konsumen tentang IMS dan HIV/AIDS.

9. Sebagian besar PSK memeriksakan dirinya ke tenaga kesehatan jika PSK sudah memiliki penyakit yang sudah cukup parah. Sebagian besar PSK mengkonsumsi antibiotik atau obat warung jika merasakan sakit. Selain itu mereka sering mengkonsumsi jamujamuan atau daun-daunan untuk menajaga kebersihan kemaluannya.

\section{DAFTAR PUSTAKA}

Andrews. 2009. Buku Ajar Kesehatan Reproduksi Wanita/ editor Gilly Andrews;alih bahasa, Sari Kurnianingsih..[et. al] ; editor edisi bahasa Indonesia, Dwi Widiarti, Renata Komalasari - Ed. 2. Jakarta: EGC Albantany, Nuraisyah. 2014. Dosa Besar kecil yang Terabaikan 
Penyebab Siksa Azab Kubur yang Pedih. Jakarta: Kunci Iman, Katalog dalam Terbitan (KDT).

Astrini, I., Indah, F.P.S., Pratiwi, R.D. and Poddar, S., 2020. Analysis of Efforts to Increase Knowledge, Attitudes, and Adherence of Antiretroviral Consumption in People With HIV/AIDS, Jepara City, Indonesia.

Christina.Manurung, Dkk. 2015 Karakteristik Pekerja Seksual Komersial dan Kejadian Penyakit Menular Seksual.: Departemen Kesehatan RI. 2006. Pedoman Pelayanan Konseling dan Testing HIV/AIDS Secara Sukarela. Jakarta: Direktorat Jendral Pengendalian Penyakit dan Penyehatan Lingkungan.

Fahmi.Irham, 2010. Manajemen kinerja. Bandung: Alfabet.

Glasier, Anna. Ailsa Gebbie. 2005. Keluarga Berencana dan Kesehatan Karoke, cafe dan Diskotek di Kota Semarang. Semarang: Tesis Program Studi Magister Promosi Kesehatan, Universitas Diponegoro

Hanifah. Utami. 2012. Kesproholic, Berani Menjadi Diri Sendiri. Jakarta: Mitra Inti Foundation

Irianto, Koes. 2015. Kesehatan Reproduksi (Reproductive Health). Bandung: CV. Alfabeta

Jumiatun, 2016. Hubungan pengetahuan wanita pekerja seks tentang perilaku seks aman dengan kejadian infeksi menular seksual di lokalisasi gambilangu kecamatan kaliwungu kabupaten Kendal: STIKes Uniska Kendal .
Kementrian Kesehatan RI. 2015. Agenda Hidup Sehat: Jilid 2.

Lokollo, Fitriana yuliawati. 2009, Studi Kasus Perilaku Wanita Pekerja Seksual Tidak Langsung Dalam Pencegahan IMS, HIV Dan AIDS Di Pub Dan Karooke, Cafe, Diskotik Di Kota Semarang. Program Pascasarjana: Universitas Diponegor Mangando, E.N. (2014).

Hubungan Antara Pengetahuan dan Sikap Remaja Dengan Tindakan Seks Pranikah pada Siswa Kelas XI di SMK Negeri Manado. Jurnal Kedokteran Komunitas dan Tropic: volume 11 Nomor 1 febuari 2014, 38.

Moleong,L.J. 2001. Metodologi penelitian kualitatif edisi revisi. Bandung: PT Remaja Rosdakarya.

Nina Maria Desi, Zahroh Shaluhiyah dan Sutopo Patriajati. 2018. Perilaku Seksual Berisiko pada Pedagang Bawang Merah di Kecamatan Wanasari Kabupaten Brebes.: Universitas Diponogora Semarang Reproduksi: Edisi 4. Jakarta: EGC Siregar, R.S. 2005. Atlas Berwarna Saripati Penyakit Kulit: Edisi 2. Jakarta: EGC.

Sugiyono. 2012. Metode Penelitian Kuantitatif, Kualitatif dan R\&D. Bandung: Alfabeta Jawa Barat dalam Angka 2015 (Jawa Barat in Figures 2015).

Jawa Barat: Badan Pusat Statistik Provinsi Jawa Barat. 2014. Jawa Barat dalam Angka 2014 (Jawa Barat in Figures 2014).Jawa Barat: Badan Pusat Statistik Provinsi Jawa Barat. 
Purwoastuti, Endang. Elisabet Siwi Walyani. 2014. Panduan Materi Kesehatan Reproduksi dan Keluarga Berencana.Yogyakarta: PT. Pustaka Baru.

Ulfah.A, 2015. Hubungan tingkat pengetahuan perawat tentang pemakaian alat pelindung diri (APD) dengan tindakan pencegahan infeksi nosokomial di RSU KOTA TANGERANG SELATAN" STIKes Widya Dharma Husada.

Dokter Indonesia Online. Angka Kejadian Penyakit Menular Seksual di Dunia dan Indonesia. Artikel ini diakses pada tanggal 2 April 2016 dari alamat website

https://dokterindonesiaonline.com/201 6/0 4/02/angka- kejadian- penyakitmenular- seksual-di-indonesia-dandunia/ 